http://ejournal.ihdn.ac.id

\title{
ATMAN MENUJU BRAHMAN \\ (Perspektif Teologi Hindu)
}

\author{
I Gusti Ngurah Elga Putra Sutrawan \\ Akademisi IHDN Denpasar \\ Email: ngurahelga@gmail.com
}

\begin{abstract}
Abstrak
Tulisan ini dilakukan berdasarkan ketertarikan penulis terhadap proses kehiduan yang penuh dengan misteri yang sulit dijelaskan melalui pengalaman indrawi. Kehidupan ini berjalan sedimikian rupa mengikuti alur yang telah ditentukan. Penentu kehidupan inilah yang disebut "karma" sebagai penentu kehidupan, kematian, kebahagiaan serta kesengsaraan manusia pada kehidupan selanjutnya yang disebut dengan "Punarbhawa" dan Karma Pula sebagai penentu kapan saatnya atma itu kembali kepada Brahman. Sehingga tidak ada lagi kesengsaraan maupun kebahagiaan yang terasa semua kembali menjadi Achintya. Mengendalikan manah dalam sapta angga, dengan cara melaksanakan Prayogasandhi dengan Samyagjnana sebagai penuntunnya serta melaksanakan Catur Yoga berdasarkan pada kebenaran dan ketulusan hati, sehingga seseorang akan mencapai kesadaran akan sang diri dan hakekat Tuhan. Setelah tercapainya kesadaran tersebut pasti seseorang akan melaksanakan sesuatu berdasarkan pada kesadaran tersebut. Perbuatan yang baik tentu akan selalu terlaksana walaupun belum sempurna. Dengan selalu melaksanakan perbuatan baik, tanpa pamrih, tulus ikhlas dan selalu ada dalam kesadaran sejati maka seseorang akan dapat terhindar dari lapisan alam bawah yang penuh dengan kesedihan dan perlahan akan meniti ke atas untuk mencapai satya loka dan pada akhir Atman akan menyatu dengan Brahman.
\end{abstract}

Kata Kunci: Atman, Brahman, Teologi Hindu 


\section{PENDAHULUAN}

Ciptaan Hyang Widhi adalah merupakan pancaran kemahakuasaan-Nya (wibhuti) Hyang Widi Wasa itu sendiri.Wibhuti ini terpancar melalui tapa.Tapa adalah pemusatan pikiran yang terkeram hingga menimbulkan panas yang terpancar. Dengan tapa inilah Hyang Widhi menciptakanalam semesta sehingga bagi kita jelaslah bahwa memerlukan pemusatan tenaga yaitu yang diamati Tapa tadi. Dalam Upanishada (Brihadaranyaka dan Chandogya-Upanishada) mengatakan :

Idam waagranai wakin cidasit, sad ewa saumyaidam agra asit Eka Ewa adwitya.

Artinya :

Sebelum di ciptakan alam ini tidak ada apaapa. Sebelum alam diciptakan hanya Hyang Widhi yang ada Maha Esa dan tidak ada duanya.

Sebelum manusia di ciptakan Hyang Widhi telah menciptakan terlebih dahulu, sesuai dengan jalannya dari yang halus ke kasar yaitu menciptakan makhluk sebagai dewa-dewa, gandharwa, pisaca, raksasa dan lain sebagainya dan makhluk berbadan kasar sebagai binatang, manusia dan lain-lainnya. Manusia pertama disebut dengan nama manu atau lengkapnya Swayambhumanu. Dengan nama ini jangan mengira bahwa Swayambhu-manu ini adalah sebuah nama perseorangan karena kalau dilihat artinya Wayambhu berarti yang menjadikan diri sendiri , (Swayam $=$ dirisendiri $;$ bhu $=$ menjadi $)$ serta manu berarti Ia yang mempunyai pikiran $($ manah $=$ pikiran). Jadi kata Swayambhu-manu berarti Makhluk berpikir yang menjadikan dirinya sendiri yaitu manusia pertama.

Zat padat dan zat-zatcairlah yang paling banyak di dunia kita ini yang dinamai Bhur loka atau Manusia Loka. Adapun Bwahloka yang juga dinamai Pitra loka atau dunia roh banyak di kuasai oleh unsure apah (zatcair) dan teja (sinar). Sedangkan Swah loka atau disebut juga Swarga (sorga) atau Dewaloka (duniaparadewa) dikuasai oleh unsur teja (sinar) dan bayu (hawa). Ketiga dunia ini yaitu Bhur, Bwah dan Swah loka di kenal juga dengan nama Tri loka (tiga dunia yang terkenal dalam puja Gayatri dan Tri Sandya). Berangkat dari penjelasan tersebut proses manusia untuk kembali kepada Hyang Widhi merupakan suatu hal yang menjadi landasan dalam kehidupan, Panca Srada adalah lima keyakinan dalam menjalani kehidupan di dunia ini yang terdiri dari Brahman, Atman, Karma Pala, Punarbhawa dan Moksa. Kelima konsep ini saling berkaitan satu dengan yang lainnya, dalam proses penciptaan dan menuju Hyang Widhi konsep Karma Pala, Punarbhawa dan Moksa sangatlah penting untuk diketahui, dimaknai dan dilaksanakan dalam kehidupan.

Dalam Slokantara, 68 dinyatakan: "Karma Phala ngaranya phala ninggawe hala hayu" maksudnya Karma phala adalah akibat phala dari baik buruk suatu perbuatan (karma). Hukum karma itu sesungguhnya amat berpengaruh terhadap baik buruknya segala mahluk dan menentukan seseorang hidup bahagia atau menderita lahir bathin. Setiap orang berbuat baik (subha karma) pasti akan membuahkan hasil yang baik demikian pula sebaliknya. Karma dan Punarbhawa ini merupakan suatu proses yang terjalin erat. Setiap karma yang di lakukan atas dorongan asubha karma akan menimbulkan dosa dan atma akan mengalami neraka serta dalam punarbhawa yang akan datang akan mengalami penjelmaan dalam tingkat yang lebih rendah, sengsara atau menderita bahkan menjadi mahluk yang hina. Sebaliknya, setiap karma yang baik (subha karma) akan mengakibatkan atma menuju sorga dan jika menjelma kembaliakan mengalami tingkat penjelmaan lebih sempurna atau lebih tinggi (Sarasamuscaya.48). Kesimpulannya dengan keyakinan akan punarbhawa ini maka orang harus sadar, bahwa bagaimanapun kelahirannya tergantung dari karma wasananya.

DalamBhagawadgita VII.19 disebutkan:

Bahunam janmanam ante jnanavan man prapadyate

Vasudevah sarwamitisa mahatma sudurlabhah.

Artinya: 
"Pada akhir kelahiran manusia, orang yang berbudi (orang yang tidak lagi terikat oleh keduniawian) datang pada-Ku karena (mereka) tahu Tuhan adalah segalanya, sungguh sukar di jumpai jiwa agung seperti itu. bahwa :

Berikutnya VIII.15 lebih di tegaskan lagi

\section{Mam upetya punarjanmanduh kalayam asasvatam \\ Napnuvantimahatm \\ paramam gatah \\ anahsamsiddhim}

Artinya:

"Setelah sampai kepada-Ku, mereka yang berjiwa agung Ini tidak lagi menjelma kedunia yang penuh dukha dan tak kekal ini dan mereka tiba pada kesempurnaan tertinggi.

"Moksartham Jagadhita ya caiti dharma" maka moksa merupakan tujuan yang terakhir atau tertinggi. Moksa adalah kebebasan dari keterikatan benda-benda duniawi dan terlepasnya atman dari pengaruh maya serta bersatu kembali dengan sumberNya.

\section{PEMBAHASAN}

\subsection{Karma phala}

Karma phala berasal dari kata karma dan phala. Karma artinya perbuatan, dan phala artinya hasil atau buah. Jadi karma phala artinya hasil dari perbuatan yang telah kita lakukan. Menurut Anandas (2007:45) menguraikan bahwa Karma artinya bukan saja perbuatan, tetapi karma juga hasil perbuatan. Sesungguhnya hasil dari perbuatan tidak bisa dipisahkan dari perbuatan itu sendiri. Sesuatu perbuatan, perkataan maupun pikiran yang menyebabkan suatu akibat disebut karma. Hukum karma adalah hukum tentang sebab dan akibat. Tidak ada satupun akibat tanpa sebab, begitupun sebaliknya.

Berdasarkan uraian tersebut jadi dapat diartikan bahwa karma phala merupakan hasil dari perbuatan seseorang. Kita percaya bahwa perbuatan yang baik (subhakarma) membawa hasil yang baik dan perbuatan yang buruk (Asubhakarma) tentu buruk pula yang akan diterima. Bahkan kepercayaan akan adanya karma phala ini dapat memberikan keyakinan kepada kita untuk mengarahkan segala tingkah laku yang dilakukan hendaknya selalu berdasarkan pada etika yang baik, keinginan yang baik dan selalu menghindari diri dari jalan serta tujuan yang buruk. Kelahiranpun merupakan bagian dari karma itu sendiri tidak. Karma merupakan takdir atau nasib seseorang, dan tidak ada jalan untuk melepaskan diri. Kadang manusia lupa bahwa suratan atau jalan kehidupannya ditulis oleh dirinya sendiri, semua ditulis oleh tangan seseorang itu sendiri, dan tangan yang menulis itu pula yang dapat menghapusnya yaitu dengan berkarma yang baik. Manusia sering beranggapan bahwa Tuhanlah yang bertindak dibalik kedukaan, kesedihan, kegembiraan dan lain-lain. Sebenarnya tuhan tidak turut campur, baik dalam ganjaran ataupun hukuman, beliau hanya mencerminkan, memantulkan dan bereaksi (Anadas, 2007:46). Tuhan adalah saksi abadi yang tidak terpengaruh. Manusialah yang menentukan nasibnya sendiri. Tuhan telah menciptakan hukum alam yang secara otomatis akan merekam dan memberikan apa yang seharusnya menjadi haknya sesuai dengan kewajiban yang dilaksanakannya. Maka dari itu lakukanlah kebaikan maka kebaikan yang akan diterima begitu pula sebaliknya ketika kita melakukan perbuatan buruk maka buruk pula yang akan didapat.

Manusia juga sering mengatakan bahwa Tuhan adalah penyebab utama segala sesuatu yang terjadi, sampai batas-batas tertentu memang benar, namun tuhan tidak pernah menjerumuskan manusia kedalam kurungan besi nasib yang tidak adapt dihindari lagi. Tuhan telah membekali manusia dengan akal (pikiran, idep).itulah yang harusnya dipergunakan dengan baik untuk mencapai suatu tujuan akhir manusia yaitu moksa. Namun untuk mencapai tujuan akhir bukanlah hal yang mudah. Manusia harus lahir berulang kali untuk memetik dan membayar buah karmanya. 
Oleh karena itu terdapat tiga karma yang berhubungan dengan masa kehidupan yakni sebagai berikut:

1. Sancita Karma Phala yaitu phala dari perbuatan kita dari perbuatan terdahulu yang belum habis dinikmati dan masih merupakan benih yang menentukan kehidupan manusia sekarang.

2. Prarabda Karma Phala yaitu phala dari perbuatan kita pada kehidupan ini habis dinikmati sekarang tanpa ada sisanya.

3. Kriyamana Karma Phala ialah hasil perbuatan yang tidak sempat dinikmati pada saat berbuat, sehingga harus diterima pada kehidupan yang akan datang.

Jadi adanya orang menderita walaupun pada kehidupannya selalu berbuat baik adalah disebabkan oleh sancita karma phala (karmanya terdahulu). Tegasnya cepat atau lambat, dalam kehidupan sekarang ataupun nanti segala phala dari perbuatan itu pasti diterima, karena sudah merupakan alam (hukum Rta).

\subsection{Hubungan Punarbhawa Sapta Loka dan Sapta Patala}

Punarbhawa ialah kelahiran yang berulangulang yang disebut juga penitisan atau Samsara.kelahiran manusia kedunia ini membawa suka dan duka. Punarbhawa atau Samsara ini terjadi karena jiwatman dipengaruhi oleh kenikmatan duniawi dan kematian yang akan diikuti oleh kelahiran. Sgala perbuatan ini menyebabkan adanya bekas (wasana dalam jiwatman. Dan bekas-bekas perbuatan atau karmawasana itu ada bermacam-macamjika bekasbekas itu hanya bekas-bekas keduniawian maka jiwatma akan lebih cenderung dan gampang ditarik oleh hal-hal keduniawian yang menyebabkan atma lahir kembali (Parisadha Hindu Dharma, 2014: 21). Jika tidak ada bekas-bekas lagi pada jiwatman, maka tidak aka nada yang menarinya ke dunia fana ini, dan atman akan bersatu dengan Brahman (Ida Sang Hyang Widhi Wasa). Yang dimana atma sadar akan hakekatnya, lepas dari ikatan keduniawiannya maka atma tidak akan dilahirkan kembali,atma akan kembali pada Sang pencipta yang merupakan tujuan akhir manusia yaitu moksa.

Namun ketika ia dilahirkan kembali, tidak selalu dilahirkan menjadi manusia yang bertempat di Bumi. Semua berdasar pada karma. Alam Semesta di dalam Hindu, memiliki strukturstruktur lapisan-lapisannya. Terdapat tingkatan dalam setiap lapisannya, yang mana tujuh lapisan keatas, kebawah, maupun lapisan yang ada dalam tubuh manusia. Lapisan dunia keatas disebut dengan Sapta Loka, lapisan dunia kebawah disebut dengan sapta patala, dan lapisan yang ada dalam tubuh manusia disebut dengan sapta angga. Dalam lapisan sapta angga, maka tentu atma akan dilahirkan menjadi manusia, namun dalam sapta patala atma ditempatkan sesuai dengan karma wasana yang dilakukannya, begitu pula pada lapisan sapta loka. Dalam bhagawadgita dijelaskan bahwa memang benar bahwa alam semesta dibedakan menjadi beberapa lapisan yaitu lapisan atas (sapta Loka), Lapisan Tengah (bumi) dan lapisan Bawah (sapta patala). Sloka dalam bhagawat gita tersebut berbunyi:

Urdhvam gacchanti sattca-stha madhye tistanti rajasah,

Jaghanya-guna-vrrti-stha adho gacchanti tamasah.

Terjemahannya:

Orang-orang yang mantap didalam sifat kebaikan akan pergi ke atas ke alam-alam yang lebih tinggi. Merkea yang berada didalam sifat-sifat kenafsuan akan pergi kealam-alam yang menengah, sedangkan yang berada dalam sifat kegelapan yang menjijikan akan meniti jalan turun (menuju alam-alam rendah.

Berdasarkan sloka diatas penulis tangkap bahwa dunia terbagi menjadi beberapa lapisan, yakni: lapisan atas yang dibagi lagi menjadi beberapa lapisan, yang disebut dengan sapta Loka; lapisan tengah yaitu Bumi beserta isinya; dan Lapisan bawah yang terbagi juga menjadi beberapa lapisan yang disebut dengan sapta patala.

Puji (2010) dalam penelitiannya yang berjudul "Konsep Kosmologi Dalam Lontar Bhuwana Sangksepa" menjelaskan bahwa 
keseluruhan lapisan ini merupakan tempat dari berbagai perwujudan dari Tuhan termasuk manusia maupun dewata. Seseorang akan mencapai pada lapisan teratas maupun terbawah, dan tetap pada lapisan sekarang, semua tergantung kepada karma yang dilakukan semasa hidupnya. Itulah sebabnya setiap ajaran Agama selalu mengajarkan kita untuk tetap berbuat sebaik mungkin, karena semakin baik perbuatan kita maka kualitas kesengsaraan dari kelahiran kembali seseorang setidaknya dapat di minimalkan. Karena setiap lapisan kelahiran tersebut memiliki kadar kesengsaraan yang berbeda, semakin kebawah kadar kesengsaraan akan semakin tinggi pula, begitupun sebaliknya semakin seseorang berbuat baik, semakin menyadari hakikat sang diri maka kelahiran manusia akan menuju lapisan atas (lapisan yang lebih tinggi) dan sampai pada akhirnya mencapai tujuan tertinggi yaitu moksa. Makrokosmos maupun mikrokosmos memiliki hubungan yang sangat erat antara satu dengan yang lainnya. Bila dalam makrokosmos terdapat lapisan atas yang disebut sapta loka, dan lapisan bawah yang disebut sapta patala, maka dalam mikrokosmos terdapat yang disebut dengan Sapta angga.

\subsubsection{Sapta Loka}

Sapta loka merupakan tujuh lapisan dunia ke atas sebagai pembentuk alam semesta. Puji (2010:115) menguraikan bahwa sapta loka merupakan tempat yang terdapat dialam semesta yang dikenal sebagai keberadaan dari bhuwana agung (makrokosmos) yang dijadikan tempat berbagai makhluk, termasuk dewa-dewa. Adapun ketujuh lapisan dunia yang berada dalam makrokosmos ini yaitu sebagai berikut :

1. Bhuhloka adalah bhumi dimana tempat kita berpijak saat ini, bersama dengan makhluk hidup lainnya dan semua ciptaan tuhan yang kita lihat sekarang ini. Bhuh loka merupakan alam tengah di antara jalan menuju keatas (Loka) maupun jalan menuju ke bawah (patala). Kelahiran di alam bhuh loka memiliki kadar yang sama antara kebahagiaan dan kesengsaraan. Maka dari itu sering kita dengar istilah bahwa "kedukaan selalu mengikuti kebahagiaan", di bali sering diucapkan bahwa " amongken sebete, amonto legane", di alam ini kita akan selalu dihadapkan dengan perasaan suka dan bahagia yang silih berganti. Hal tertinggi yang harus dicapai untuk menghilangkan keterikatan dua hal tersebut yaitu mencapai kesadaran sejati di dunia.

2. Bhwahloka merupakan lapisan kedua setelah Bhuloka. Pada lapisan ini Candraditya (bulan dan matahari) sebagai dewatanya, dan pada umumnya ditempati oleh para raksasa yang memiliki setengah sifat kebaikan (keilahian), yang di dalamnya hanya terdapat langit dan udara.

3. Swahloka merupakan lapisan dunia yang dipimpin oleh Dewa Indra dan wisnu sebagai dewatanya. Lapisan ini pada umumnya juga disebut dengan Swargaloka atau sorga yang merupakan kediaman dari para Dewata. Lapisan badan yang dipakai di alam ini adalah karana sarira (sukshma sarira sudah terurai bersih). Sang jiwa akan lahir di alam ini karena dalam hidupnya dia bathinnya bersih dan banyak melakukan kebaikan. Sang jiwa akan merasakan kebahagiaan dan kedamaian yang berlimpah. Jauh melebihi kebahagiaan dan kedamaian dalam kehidupan biasa yang kita rasakan di bumi. Hal ini tidak bisa dijelaskan, kecuali kalau kita pernah mengalami samadhi dalam meditasi, sedikit banyak akan paham maksudnya. Akan tetapi lahir di Svarga Loka belum menghentikan roda samsara, ada waktunya nanti sang jiwa harus kembali lahir ke dunia untuk melanjutkan evolusi bathinnya serta menyelesaikan sisa putaran karmanya sendiri.

4. Mahaloka merupakan lapisan dunia yang terdiri dari pada rsi, pada lapisan dunia ini dipimpin oleh Rsi Brigu dan Brahma adalah dewatanya. Para Rsi ini berada di dalam Mahaloka dikarenakan melakukan yadnya api yang sangat besar. Para Rsi ini juga dijelaskan dapat berpindah dari satu 
planet yang lainnya. Lapisan badan yang dipakai di alam ini adalah vijnanamaya kosha (karana sarira sudah terurai bersih). Sang jiwa akan lahir di alam ini karena dalam hidupnya dia merealisasi kesadaran, hanya saja belum sempurna. Lahir di Maha Loka berarti roda samsara (siklus kehidupan-kematian) telah berhenti. Sang jiwa bisa melanjutkan evolusi bathinnya dan menyelesaikan sisa putaran karmanya di lapisan alam ini juga. Akan tetapi banyak juga jiwa yang lahir di lapisan alam ini karena welas asih memutuskan untuk reinkarnasi kembali. Lahir ke dunia menjadi satguru yang terang dan membebaskan bagi umat manusia, sekaligus untuk melanjutkan evolusi bathinnya.

5. Janaloka merupakan lapisan dunia tempat kediaman dari Sapta Rsi dan Rudra sebagai dewatanya. Sapta Rsi ini merupakan tujuh rsi yang menerima wahyu veda dan menyebarkannya ke bumi. Lapisan badan yang dipakai di alam ini adalah vijnanamaya kosha. Sang jiwa akan lahir di alam ini karena dalam hidupnya dia merealisasi kesadaran (lebih sadar dari jiwa yang lahir di Maha Loka), tapi tetap saja belum sempurna. Lahir di Jana Loka berarti roda samsara (siklus kehidupan-kematian) telah berhenti. Sang jiwa bisa melanjutkan evolusi bathinnya dan menyelesaikan sisa putaran karmanya di lapisan alam ini juga. Akan tetapi banyak juga jiwa yang lahir di lapisan alam ini karena welas asih memutuskan untuk reinkarnasi kembali. Lahir ke dunia menjadi satguru yang terang dan membebaskan bagi umat manusia, sekaligus untuk melanjutkan evolusi bathinnya.

6. Tapaloka ini merupakan lapisan dunia yang mana memiliki tingkatan anugrah. Sang Hyang Mahadewa sebagai dewatanya. Di alam ini merupakan kualitas dari jutaan materi yang lebih besar maupun lebih kecil dalam lapisan dunia. Menurut Bath Dalam kuliah umumnya, Tapaloka ini didiami oleh 4 kumara yang bernama Sanat, Sanak, Sanandan dan Sanatan. Lapisan badan yang dipakai di alam ini adalah vijnanamaya kosha. Sang jiwa yang lahir di alam ini menjadi apa yang disebut kesadaran kosmik. Dengan cara yang rahasia beliau tidak perlu turun lahir ke dunia, beliau selalu membimbing umat manusia, semua mahluk-mahluk lainnya, serta termasuk membimbing para dewa di loka sebelumnya menuju penerangan dan pembebasan.

7. Satyaloka merupakan lapisan dunia yang di diami oleh Siwa, diakui sebagai realitas tertinggi. Lapisan ini merupakan lapisan tertinggi dari ketujuh lapisan yang dijelaskan sebelumnya. Lapisan ini juga dapat dikatakan sebagai dunia yang hanya ada kebenaran. Lapisan badan yang dipakai di alam ini adalah anandamaya kosha [vijnanamaya kosha sudah terurai bersih]. Sang jiwa yang lahir di alam ini menjadi apa yang disebut maha-kesadaran kosmik. Kesadaran beliau sedikit lagi sempurna untuk bisa menyatu (manunggal) dengan yang maha tidak terpikirkan (Brahman). Dengan cara yang rahasia (tidak perlu turun lahir ke dunia) beliau selalu membimbing umat manusia, semua mahluk-mahluk lainnya, serta termasuk membimbing para dewa di ke-empat Loka sebelumnya menuju penerangan dan pembebasan.

\subsubsection{Sapta Patala}

Sapta patala merupakan kebalikan dari sapta loka. Bila sapta loka menuju keatas maka sapta patala menuju ke bawah. Tujuh wilayah di bawah Bumi yang terdiri atas Atala, Witala, Sutala, Rasatala, Tala-tala, Mahatala dan Patala. Ketujuh lapisan inilah yang disebut dengan Sapta Patala. Adapun sapta patala tersebut dapat diuraikan sebagai berikut:

1. Atala merupakan lapisan dibawah Bumi yang berisikan jiwa yang selama hidupnya tidak melaksanakan wacika parisudha. Jiwa 
ini selalu menjelaskan segala sesuatu yang tidak benar misalnya berbohong, menfitnah dan lain-lain. Penghuninya adalah para wong samar. Mereka yang masuk alam ini biasanya disaat kematian, karma buruknya lebih dominan dibandingkan dengan karma baiknya dan pikiran buruknya lebih dominan dibandingkan dengan pikiran luhurnya. Sehingga saat kematian tiba dia akan gagal menemukan jalan terang. Sumber kesengsaraan utama di alam ini adalah pikiran dan ingatan (kenangan) akan rasa bersalah, rasa tersinggung [marah], rasa tidak terima, rasa sakit fisik, dan sebagainya. Sumber kebahagiaan utama di alam ini adalah pikiran dan ingatan (kenangan) akan kasih sayang dan kebaikan-kebaikan yang pernah dilakukan.

2. Witala merupakan lapisan yang berisikan jiwa yang selama hidupnya memendam banyak kekecewaan, dendam atau sakit hati, selain juga tidak punya tabungan karma baik yang mencukupi. Juga mereka yang mati mendadak dalam kondisi sengsara atau salah pati seperti misalnya karena : kecelakaan, dibunuh, dan sebagianya. Tanpa punya akumulasi karma baik yang mencukupi. Sehingga saat kematian tiba dia akan gagal menemukan jalan terang. Termasuk mereka yang mati bunuh diri juga akan cenderung masuk alam ini. Penghuni dimensi alam witala ini sangat beragam, yaitu berbagai macam mahluk-mahluk yang wujudnya ganjil dan aneh-aneh, seperti wujud dengan badan rusak atau tidak lengkap, kepala berkaki tanpa tubuh dan tangan, berwujud bola dengan lidah-lidah api, wujud yang menjijikkan, berwujud bola mata merah menyala, dsb-nya. Sumber utama kesengsaraan di alam ini adalah pikiran dan ingatan (kenangan) akan berbagai kekecewaan, ketidakpuasan dan keinginankeinginan pikiran yang tidak terpenuhi. Juga berbagai dendam dan sakit hati yang menurut mereka harus dilampiaskan.
3. Sutala merupakan Penghuni alam ini adalah para preta, mahluk berwujud manusia kurus, berwajah pucat dan suara melengking atau suara histeris. Ada juga mahluk yang wujudnya manusia kumal, dengan rambut kusut kotor. Selain itu ada juga mahluk-mahluk mirip seperti manusia di alam ini yang terus mengejar hasrathasrat duniawi palsu, tapi semuanya akan berujung kepada siksaan dan kesengsaraan. Kejadian ini, yaitu mengejar hasrat-hasrat duniawi palsu yang kemudian berujung kepada siksaan dan kesengsaraan, akan terus terjadi berulang-ulang dan berulang kembali di alam ini.

Alam sutala ini memiliki banyak duniadunia tersendiri, dalam satu dimensi yang sama. Dinamika alam, pengalaman dan wujud para penghuninya juga ada beberapa perbedaan satu sama lain. Mereka yang masuk alam ini biasanya yang dimasa kehidupan gemar sekali mengumbar hawa nafsu indriya [hedonis] dan serakah mengejar berbagai macam kenikmatan dan kepuasan-kepuasan lainnya. Selain juga tidak punya akumulasi karma baik yang mencukupi. Pada dasarnya mereka bukan mahluk-mahluk yang jahat, hanya saja tingkat kesadaran dan kebijaksanaannya lebih rendah dari manusia pada umumnya, sehingga mereka tidak mampu mengendalikan dirinya.

Dan proyeksi energi negatif dan kondisi berat alam sutala ini juga mempengaruhi dan membuat mereka seperti itu. Sumber kesengsaraan di alam ini adalah pikiran dan ingatan (kenangan) akan berbagai keinginan-keinginan badan dan pikiran yang tidak terpenuhi, seperti nafsu seks yang dilampiaskan sepuas-puasnya sampai maksimal, makan enak yang dilampiaskan sepuas-puasnya sampai maksimal, dsb-nya. Sumber kebahagiaan utama di alam ini adalah pikiran dan ingatan (kenangan) akan keinginan-keinginan badan dan pikiran yang tidak pernahn terpuaskan. 
4. Tala-tala merupakan Penghuni alam ini adalah para rakshasa, makhluk bertubuh tinggi-besar, berkulit hitam, berwajah sangar dan seram. Ini adalah lapisan alam gelap yang menjadi habitat bagi jiwa-jiwa yang hanya sedikit saja punya rasa welas asih dan dominan punya bathin gelap seperti : iri hati, kemarahan, ketidakpuasan, dendam dan kebencian. Alam tala-tala ini memiliki banyak dunia-dunia tersendiri, dalam satu dimensi yang sama. Wujud para rakshasa ini juga berbeda-beda, misalnya kulitnya ada yang tidak berbulu, ada yang berbulu seperti rambut, ada yang berbulu duriduri tajam seperti jarum, dsb-nya. Mereka yang masuk alam ini biasanya semasih hidup punya akumulasi karma buruk yang bertumpuk-tumpuk. Yang jiwanya dominan dengan rasa iri hati, serakah, tidak puas, kemarahan, dendam dan kebencian. Sering melakukan kekerasan dan teror fisik maupun mental kepada orang lain. Lihatlah pada manusiamanusia yang pikirannya jarang welas asih, mementingkan diri sendiri, cenderung suka mengintimidasi dan menyebarkan jejakjejak kemarahan, kebencian dimana-mana. Termasuk mereka yang semasa hidupnya belajar ilmu hitam atau ilmu-ilmu kesaktian lainnya dan menggunakannya untuk menyakiti dan menyiksa orang lain. Kecenderungan bathin mereka selalu ingin lebih hebat [lebih sakti] dari yang lain, tidak punya toleransi kepada yang lebih lemah, penuh prasangka buruk, rasa curiga, iri hati, serakah, tidak puas, marah, dendam dan benci. Sumber kesengsaraan utama di alam ini adalah siksaan mental yang mendalam akibat dari siksaan mental yang ekstrim [iri hati, marah, benci, dendam, debagainya. Serta proyeksi energi negatif dan kondisi berat alam ini yang semakin menekan. Sumber kebahagiaan utama di alam ini adalah pikiran dan ingatan (kenangan) akan puasnya melampiaskan kebencian, ketidak-puasan, dendam dan amarah yang menyebabkan orang lain menderita.

5. Tala merupakan lapisan yang di huni oleh para mahluk yang mudah berubah menjadi beragam wujud. Sering disebut para siluman. Dari wujud yang sangat buruk sampai wujud yang sangat indah. Kadang wujudnya seperti manusia, kadang wujudnya binatang, kadang wujudnya naga, kadang wujud lainnya. apabila mereka hadir di dimensi halus alam marcapada (alam manusia) biasanya hadir dalam wujud binatang seperti ular, harimau, dan sebagainya. Alam tala ini memiliki banyak dunia-dunia tersendiri, dalam satu dimensi yang sama. Suasana alam dan wujud para penghuninya juga ada beberapa perbedaan satu sama lain. Mereka yang masuk alam ini biasanya semasih hidup punya akumulasi karma buruk yang bertumpuktumpuk. Yang punya ego dan sifat manipulatif yang kuat serta banyak melakukan kesalahan-kesalahan berbahaya bagi banyak orang. Mungkin pernah dalam masa kehidupannya dia baik secara fisik maupun melalui perkataan dan pikiran seperti melaksanakan hinaan, fitnah, penipuan, manipulasi, ajaran spiritual palsu, hasutan, dan sebagainya, yang menyebabkan seseorang atau sekelompok orang mengalami kesengsaraan atau kebingungan panjang dan mendalam. Misalnya : melakukan korupsi dengan dampak besar, melakukan penipuan besar kepada sekelompok orang, mengeksploitasi tenaga kerja, berpura-pura menjadi guru spiritual padahal ajarannya tidak benar, yang tujuan sesungguhnya hanya untuk kepentingan pribadi, memuaskan ego dan keserakahan religiusnya, dan sebagainya.

6. Santala merupakan lapisan yang dihuni para mahluk yang tidak mewujud, hanya berwujud bayangan halus atau kabut yang lembut. Sering disebut para lelembut. Kehadiran mereka akan menghabiskan energi yang hidup bagi lingkungan sekitar 
maupun bagi mahluk lain termasuk manusia. Sesama makhluk-mahluk alam bawah pun juga tidak tahan berdekatan dengan mereka. Hanya mereka yang memiliki kemampuan supranatural tinggi yang bisa berhadapan dengan mereka tanpa terhisap energi hidupnya. Mereka yang masuk alam ini biasanya semasih hidup punya akumulasi karma buruk yang bertumpuk-tumpuk. Yang jiwanya dominan dengan rasa keras, serakah, tidak puas, kemarahan dendam dan kebencian. Umumnya yang masuk alam ini adalah mereka yang aktif menyebarkan propaganda yang memecah-belah manusia. Terutama mereka yang pernah melakukan kesalahan-kesalahan berbahaya bagi banyak orang seperti melakukan penganiayaan, memanipulasi atau mengorganisir kebencian pada orang lain [melalui orasi, ideologi, ajaran spiritual, dsb-nya] yang sampai pada terjadinya aksi kekerasan fisik kepada sekelompok orang atau bahkan memicu peperangan antar wilayah. Lihatlah pada manusia-manusia yang haus darah, senang dengan kekacauan, serta puas melihat ketakutan, kepedihan, dan penderitaan. Alam rasatala ini memiliki banyak dunia-dunia tersendiri, dalam satu dimensi yang sama. Sumber kesengsaraan utama di alam ini adalah akan merasakan kesengsaraan mental yang sangat berat, akibat proyeksi energi negatif dan kondisi alam berat yang tidak terhingga di alam ini. Hampir tidak ada kebahagiaan di alam ini. Termasuk tersiksa akibat perbudakan mental dan manipulasi dari jiwajiwa gelap yang menjadi raja atau penguasa di alam ini, serta sang jiwa merasa demikian putus asa akibat kecilnya peluang untuk bisa keluar atau bebas dari alam ini. Sumber kebahagiaan utama di alam ini adalah setitik harapan kecil bahwa suatu hari akan ada mahluk suci yang menolong keluar dari kesengsaraan panjang dan mendalam ini.
7. Patala merupakan dimensi alam bawah yang paling mengerikan. Sulit untuk diceritakan. Mereka yang masuk alam ini biasanya semasih hidup punya akumulasi karma buruk yang bertumpuk-tumpuk dan melakukan kesalahankesalahan fatal. Dimensi alam ini adalah apa yang disebut sebagai Naraka Loka [neraka]. Di alam ini berlaku hukum rimba, dimana yang kuat yang berkuasa. Alam patala atau Naraka Loka ini memiliki banyak sekali duniadunia tersendiri, dalam satu dimensi yang sama. Sumber kesengsaraan di alam ini adalah akan merasakan kesengsaraan mental yang sangat berat, akibat proyeksi energi negatif yang ekstrim dan kondisi alam berat ektrim yang tidak terhingga di alam ini. Termasuk tersiksa akibat penyiksaan, konflik, persaingan dan peperangan abadi antar sesama mereka. Tidak ada kebahagiaan sedikitpun di alam ini. Sangat sulit untuk keluar dari alam ini.

\section{SKEMA PROSES ATMA MENCAPAI MOKSA}

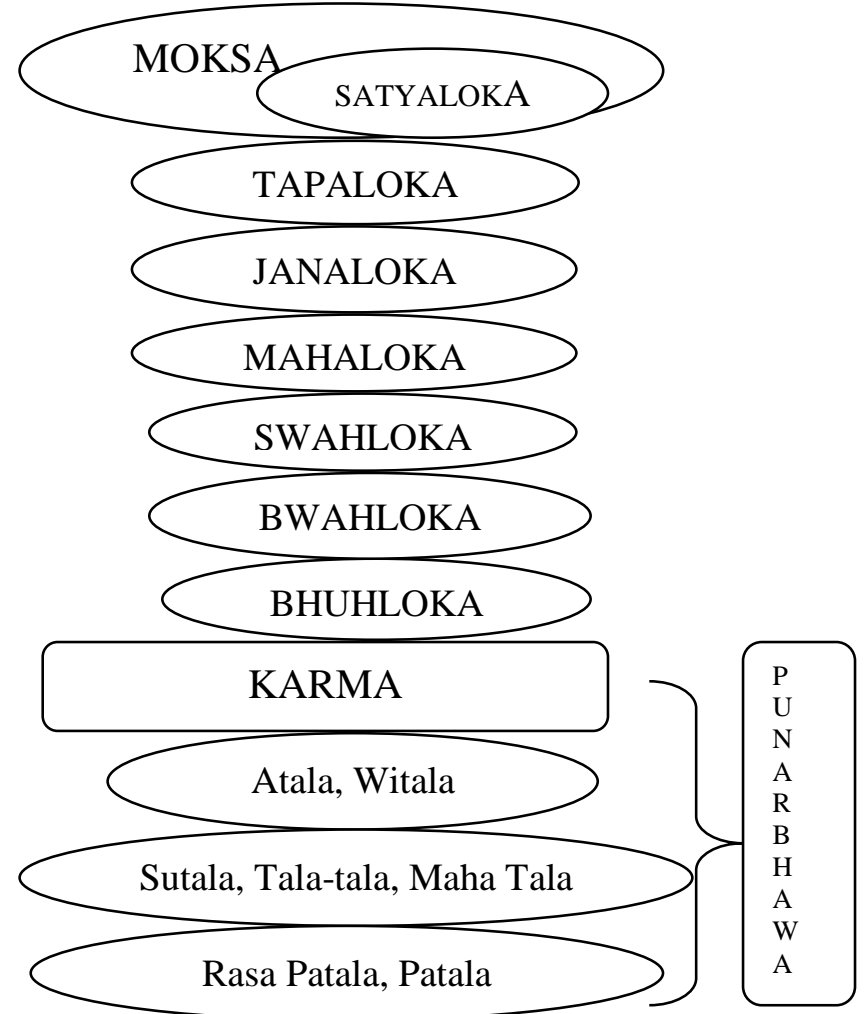




\subsection{Prayogasandhi, Samyagjnana dan Catur Yoga Sebagai Jalan Menuju Brahman}

Moksa berarti kebebasan dari ikatan keduniawian untuk mencapai, bebas dari karmaphala, bebas dari Samsara, moksa akan tercapai bukan hanya setelah manusia mengakhiri hidupnya di dunia ini, tetapi di dalam dunia ini pun moksa ini di capai (Parisada Hindu Dharma,2014:23).

Tujuan utama makhluk hidup di dunia ini tanpa kecuali manusia itu sendiri adalah mencapai Moksa. Untuk mencapai moksa seseorang hendaknya mengetahui hakekat Tuhan. Mengetahui bahwa dirinya bersumber dari tuhan dan akan kembali kepada tuhan. Manusia seringkali lupa akan hakekat sendiri, selalu mengejar materi yang membahagiakan di dunia ini tanpa ia ketahui bahwa kebahagiaan itulah yang akan membuat kesengsaraan yang lebih mendalam di kehidupannya. Dalam tattwa jnana dijelaskan tentang penyebab ketidak sadaran manusia disebut dengan Ambek atau pikiran. Ambek itulah yang dijadikan wujud Sang Hyang Atma pada diri manusia. Ambek yang menyatu dengan Badan itu disebut dengan Angga Pradhana. Angga adalah badan dan Ambek adalah Pradhana. Anggapradhana inilah yang menyebabkan Ambek menyatu dengan apa yang disebut baik dan buruk. Dari ambek ini pula baik dan buruk itu timbul, suka dan duka, bahagia, kecewa dan lain-lain. Dari Ambek ini pula timbulnya rasa menikmati objek kenikmatan melalui Dasendrya, sehingga Ambek meresap dalam dunia kenikmatan tersebut. Itulah sebabnya Dasendrya hendaknya ditarik dari objek keinginan, dan kendalikan kedalam ambek tersebut, dari Ambek kembalikan ke dalam Pramana, dari Pramana kmbalikan kedalam Dharma Wisesa, dari Dharma Wisesa kembalikan kedala Anta Wisesa dan Dari Anta WIsesa kembalikan kedalam Ananta Wisesa hingga kembali menyatu Sang Parama Siwa. Itulah pentingnya mengendalikan pikiran (manah) yang terdapat dalam sapta Angga tersebut untuk dapat mencapai kesadaran sejati.

Hal-hal yang dapat dilakukan untuk melakukan pengendalian tersebut dalam Tattwa
Jnana juga dijelaskan dengan menggunakan Prayoghasandhi dan Samyagjnana (pengetahuan yang benar) sebagai penuntun dalam pelaksanaan Prayoga Sandhi tersebut. Adapun bagian bagian dari Prayogasandhi tersebut adalah sebagai berikut:

1. Asana. Asana terdiri dari padmasana, wajrasana, payyangkasana, swastikasana, widyasana, dan mandasana. Demikianlah asana itu enam jenisnya namun hakekatnya satu. Itu lah hendaknya yang dipilih oleh orang yang melatih prayogasandhi ketika ia hendak duduk.

2. Pranayama. Yaitu usaha untuk mengatur nafas, menyimpan sang hyang urip, usahakan supaya menyatu setelah sang hyang urip tersimpan barulah mulai melaksanakan pranayama. Dalam melakukan pranama terdapat tiga wayu (angin) pembasuh diantaranya recaka, puraka, dan kumbaka. Recaka ialah mengeluarkan nafas lebih dahulu dari mulut, diamkan dan usahakan kunci, tahan sekuat tenaga mengunci. Puraka ialah menghirup nafas kembali. Dan kumbaka ialah setelah menghirup nafas, tahan, kunci kuat-kuat. Setelah dapat mengunci hembuskan keluar melalui netradwara (pintu mata). Bila belum berlatih, keluarkan melalui hidung pelan-pelan. Bila payah hentikanlah. Tujuan pranayama yakni untuk menjadikan rajah dan tamas teduh kedalam terangnya sattwam dan jangan hanya pada jasmani saja. Ketika melaksanakannya maka rasakanlah pendeknya cetana saja dibiarkan bercahaya terang, dudukkan pada kentalipuspa (bunga pisang). Bila sudah ditempatkan disana, akan terdengar hati hati yang teduh, terus sampai ke antahkarana. Itulah yang disebut memuja pranasandhilajati, yaitu pujajati, sembah Hyang suksma. Bila sudah demikian maka melaksanakan samdhi itu sudah tajam. Benar-benar hilanglah wayu (nafas) yang kasar, mati lenyap ke asalnya, sebab atma itu tak dapat dipikirkan.

3. Pratyaharayoga. Usaha yang dilakukan 
dengan menarik semua dari objek kenikmatan, kumpulkan dalam citta, budhi, dan manah. Janganlah biarkan ia pergi kesana kemari, pusatkan ia pada pikiran yang tak terganggu apapun.

4. Dhyanayoga. Bhatin yang tidak mendua, tidak berobah-obah, jernih, dengan enaknya, tetap teguh tanpa ditutupi apaapa.

5. Dharanayoga. Ada om kara sabda bertempat dalam hati, hendaknya itu pegang kuat-kuat. Itulah yang menghilangkan apa yang didengar pada waktu melaksanakan yoga, itulah sunya. Dalam keadaan demikian bhatara siwa berwujud siwatma.

6. Tarkkayoga. Seperti halnya Sang hyang paramartha (hakekat yang tertinggi) adalah konon agkasa, bedanya dengan akasa ialah tidak ada suara padanya. Demikianlah hakekat paramartha itu bedanya dengan awang-awang, persamaannya adalah samasama jernih.

7. Samadhi. Bathin yang tidak mengenal, tidak lupa, tidak mengharap apa-apa, tidak ada sesuatu yang ingin dicapai, jernih tanpa ada yang hilang, tidak ditutupi apa-apa, maka sang hyang tanpa kesulitan, karena ia tidak lagi memikirkan badan jasmani, bebas dari catur kalpana (dikenal, mengenal, dan membuat kenal, semua kembali kedalam pikiran, awal cetana dihadirkan. Maka tercapailah kesadaran sejati dalam diri.

Prayoghasandi dapat dilakukan oleh orangorang yang memiliki penuntun yang kuat. Penuntun itu adalah Samyagjnana, Karena tanpa adanya Samayagjnana maka Sang Jiwa akan meluncur tanpa memiliki tujuan yang pasti, seorang akan merasa sangan kebingungan, dan tidak tau kemana sasaran jiwanya. Oleh karena itu Prayoghasandhi hendaknya dilaksanakan dengan Samyagjnana sebagi penuntunya. Selain prayoga sandhi adapula cara lain yang dilakukan untuk mencapai Brahman yakni dengan melaksanakan Catur Yoga dengan teguh ( Parisadha Hindu Dharma,2014:23). Catur Yoga adalah empat cara mencari kesatuan dengan Ida Sang Hyang Widhi Wasa. Dalam melaksanakan catur Yoga hendaknya dapat dilaksanakan dengan dasar Dharma (kebenaran, kebaikan) dan Rasa Tulus Ikhlas. Adapun bagian dari Catur Yoga adalah sebagai berikut:

1. Jnana Yoga Yaitu menyatukan diri dengan Ida Sang Hyang Widhi dengan cara mengabdikan pengetahuan seperti, mempelajari segala pengetahuan, mengamalkan pengetahuan, serta merealisasikan pengetahuan dengan baik.

2. Bhakti Yoga Yaitu menyatukan diri dengan tuhan dengan cara melakukan kebaikan dan kesujudan yang tulus dengan dasar ketulusan hati.

3. Karma Yoga Yakni dengan melaksanakan perbuatan-perbuatan yang mulia dan bermanfaat tanpa pamrih.

4. Raja Yoga yakni dengan melaksanakan Bratha, Tapa, Yoga dan Semadhi sebagai bentuk pengendalian diri dari ikatan keduniawian.

Demikianlah hal-hal yang dilakukan dalam mencapai Brahman. Semua cara dalam Catur Yoga ini diatur sedemikian rupa setelah disesuaikan dengan kepribadian, watak dan kesanggupan manusia. Jika seseorang kesanggupannya itu terletak pada mencari Ilmu pengetahuan dan ilmu kesucian maka ajaran Jnana-Yogalah yang seyogyanya dilakukan. Jika seorang itu mempunyai watak yang halus dan perasa dan mempunyai ketekunan dalam memuja Sang Hyang Widhi maka cara Bhakti-Yogalah yang hendaknya dilakukan, jika seseorang memiliki kesanggupan pada melaksanakan pekerjaan dan pengabdian yang tulus tanpa pamrih maka ajaran KarmaYogalah yang harus dijalaninya. Sedangkan Bila orang yang tekun bersemadhi, melaksanakan bratha serta tidak dapat dipengaruhi oleh hal-hal yang bertentangan yang ada dalam hidup ini maka Raja yogalah yang dilakukan.

\subsection{Hubungan Karma, Punarbhawa, dan Moksa}

Sebelum masuk pada hubungan Karma, punarbhawa dan Moksa, hendaknya terlebih 
dahulu seseorang mengetahui unsure pembentuk manusia yang sangat berpengaruh dalam berkharma. Adapun unsure pembentuk manusia yakni sebagai berikut: Sapta angga merupakan tujuh lapisan tubuh manusia. Dalam Wrhaspatitattwa sloka 62 menjelaskan bahwa

"Prthiwi, apah, teja, wayu, akasa, budhi, manah, yeka sapta angga ngaranya"

Terjemahan:

Tanah (Prthiwi), Air (apah), Cahaya (teja), Udara (wayu), ether (akasa), akal (buddhi) dan pikiran (manah), itulah yang disebut dengan Sapta Angga.

Menurut sloka diatas berarti bahwa Sapta Angga terdiri dari unsur-unsur Panca Maha Bhuta ditambah dengan Budhi (akal) dan manah (pikiran). Dimana sapta angga merupakan lapisan yang membentuk manusia. Sehingga manusia melaksanakan sesuatu dengan badan kasar (stula sarira) dan menentukan apa yang harus dilakukan dengan badan halus (suksma sarira atau Budhi dan manah). Apabila sumber penentu keputusan yaitu Budhi dan Manah tersebut sudah dapat dikendalikan dengan baik maka tentu setiap yang kita lakukan sudah berdasarkan pada wiweka yang baik dan benar.

Manusia terlalu sibuk berperang dengan bagian dari sapta angga yang paling licah dalam diri manusia, bagian itu adalah Manah (pikiran) yang masih terikat dengan segala hal-hal yang bersifat duniawi, seperti terikat dengan kenikmatan melalui dasendrya, terikat dengan dualisme baik dan buruk, tampan dan cantik dan lain-lain. Hingga manusia lupa mempersembahkan waktunya untuk pikirannya, kebijaksanaanya, dan bhatinnya untuk melakukan hal-hal yang lebih baik untuk kenyamanan dalam hatinya. Kenyamanan yang sebenarnya yaitu hakikat dari Sang diri tersebut. Hendaknya pikiran tersebut dapat dikendalikan dengan melaksanakan Prayogasandhi guna untuk menarik segala Indiya yang menyebabkan ikatan yang semakin mendalam akan kenikmatan duniawi. Orang yang ingin mencapai moksa hendaknya mulai mencapai kesadaran akan hakekat sang diri, dan mulai memahami akan hakekat tuhan. dalam hidup ini kita mengenal akan adanya hukum karma phala bahkan kita percaya dengan hal tersebut. Hukum alam yang merealisasikan bahwa lahir hidup mati itu akan menjadi siklus yang tidak akan pernah berubah. Ketika manusia sudah mengetahui bahwa kematian itu adalah hal yang pasti hendaknya seseorang telah menyiapkan hal tersebut mulai sekarang dengan cara menabung karma baik, guna untuk mencapai tujuan akhir hidup ini yakni Moksa. Agar terhindar dari kelahiran kembali yang disebut dengan Samsara atau Punarbhawa.

Punarbhawa merupakan kelahiran kembali seseorang untuk menyelesaikan karma yang belum tuntas diselesaikan pada kehidupannya tersebut. Karma yang diakibatkan oleh ketidak sadaran akan sang diri, dan keterikatan akan keduniawian. Seseorang akan lahir kembali sesuai dengan karma yang dilakukan semasa hidupnya. Apabila dalam hidupnya selalu melakukan perbuatan yang buruk maka ia akan turun meniti lapisan Sapta Petala. Dan dalam lapisan tersebut ia kembali akan dilahirkan sesuai dengan prosentase Karma buruk yang dilakukannya. Yang dimana dalam sapta patala tersebut telah dijelaskan diatas terdapat tujuh lapisan mulai dari dibawah Bumi yaitu dri lapisan Atala sampai dengan Lapisan Patala yang merupakan Maha Neraka yang tanpa kebahagiaan sedikitpun. Begitupula apabila seseorang selalu berbuat baik, menyadari akan sang diri, tanpa pamrih dalam segala hal yang dilakukan sampai ada dalam kesadaran sejati maka seseorang tersebut akan meniti ke atas menuju alam Sapta Loka, yang juga terdiri dari tujuh lapisan. Lapisan pertama dimulai dari Bhuhloka yaitu Bumi tempat kita berpijak sampai pada alam Satyaloka dimana di alam satya loka merupakan tempat bagi manusia kosmik yang di dalamnya hanya ada kebenaran. Di alam ini di kuasai oleh Siwa dan alam inilah Alam trakhir pada kesadaran tertinggi untuk mencapai Brahman (Tuhan).

\section{SIMPULAN}

Dari pembahasan tersebut diatas dapat ditarik kesimpulan bhawa untuk mencapai Brahman manusia harus memahami hakekat sang diri, mampu mengendalikan manah dalam sapta 
angga, dengan cara melaksanakan Prayogasandhi dengan Samyagjnana sebagai penuntunnya serta melaksanakan Catur Yoga berdasarkan pada kebenaran dan ketulusan hati, sehingga seseorang akan mencapai kesadaran akan sang diri dan hakekat Tuhan. Setelah tercapainya kesadaran tersebut pasti seseorang akan melaksanakan sesuatu berdasarkan pada kesadaran tersebut. Perbuatan yang baik tentu akan selalu terlaksana walaupun belum sempurna. Dengan selalu melaksanakan perbuatan baik, tanpa pamrih, tulus ikhlas dan selalu ada dalam kesadaran sejati maka seseorang akan dapat terhindar dari lapisan alam bawah yang penuh dengan kesedihan dan perlahan akan meniti ke atas untuk mencapai satya loka dan pada akhir Atman akan menyatu dengan Brahman.

\section{DAFTAR PUSTAKA}

Anandas. 2007. Hukum Karma dan Cara Menghadapinya. Surabaya: Paramita.

Dunia, I Wayan. 2009. Kumpulan Ringkasan Lontar. Surabaya: Paramita.

Parisadha Hindu Dharma. 2014. UPADESA. Denpasar: ESBE Buku .

Pujiani. 2014. Konsep Kosmologi Dalam Lontar Bhuwana Sang Ksepa. Denpasar: Fakultas Brahma Widya, Institut Hindu Dharma Negeri Denpasar.

http:// Hindualukta.blogspot.co.id/2015/03/Tri Loka-pertama-bhur-loka-alam-alam.html. 